\title{
HAK ATAS KEBEBASAN BERAGAMA/BERKEYAKINAN: SEBUAH UPAYA PENDASARAN FILOSOFIS
}

\author{
Iqbal Hasanuddin \\ Universitas Islam Negeri Syarif Hidayatullah Jakarta
}

\begin{abstract}
This paper tries to give a philosophical foundation to the rights to freedom of religion/belief. So far, the rights to freedom of religion/belief have been considered legitimate because it was the result of General Assembly of the United Nations as mutual consensus of all nations around the world. Although, the normativity of the rights to freedom of religion/belief based on that mutual consensus is not ethical-philosophical, but political. By the justice argument of John Rawls and the self-ownership argument of Robert Nozick, this paper tries to give a moral foundation for the guarantee of respect and protection of the freedom of religion/belief.
\end{abstract}

KEYWORDS: freedom of religion/belief, Human rights instruments, forum internum, forum eksternum, justice, self-ownership.

ABSTRAK: Tujuan makalah ini adalah memberikan pendasaran filosofis bagi hak atas kebebasan beragama/berkeyakinan. Sejauh ini, hak atas kebebasan beragama/berkeyakinan (KBB) dipandang sebagai sesuatu yang bersifat normatif, karena dihasilkan dalam sidang-sidang Majelis Umum Perserikatan Bangsa-bangsa (PBB) sehingga telah menjadi konsensus bersama bangsa-bangsa di seluruh dunia. Namun demikian, normativitas hak atas KBB yang didasarkan pada konsensus bersama itu masih bersifat politis, belum memiliki dasar etis-filosofis. Melalui argumen keadilan yang didasarkan pada pemikiran John Rawls dan argumen kepemilikan-diri yang didasarkan pada pemikiran Robert Nozick, makalah ini mencoba memberikan landasan moral bagi jaminan penghormatan dan perlindungan bagi kebebasan beragama/berkeyakinan. 
KATA-KATA KUNCI: kebebasan beragama/berkeyakinan, instrumen-instrumen HAM, forum internum, forum eksternum, keadilan, kepemilikan-diri.

\section{Pengantar}

Salah satu persoalan filosofis paling penting terkait dengan hak atas kebebasan beragama/berkeyakinan adalah berkenaan dengan pertanyaan landasan filosofis apa yang bisa dijadikan justifikasi untuk hak atas kebebasan beragama/berkeyakinan tersebut? Landasan filosofis itu sangat penting mengingat sejauh ini normativitas yang mendasari kebebasan beragama/berkeyakinan adalah posisinya sebagai bagian dari hak-hak asasi manusia (HAM) yang merupakan hasil konsensus internasional yang bersifat politis. Dengan demikian, alasan di balik keharusan ditegakkannya kebebasan beragama/berkeyakinan adalah karena ia bagian dari hukum internasional, dan bahkan nasional yang mengikat secara hukum. Tapi, pertanyaannya adalah mengapa secara moral kebebasan beragama/ berkeyakinana itu bersifat normatif? ${ }^{1}$

Secara umum, berbagai tradisi filsafat telah memberikan kerangka dasar untuk menjustifikasi prinsip kebebasan manusia, atau secara khusus kebebasan berpikir dan kebebasan beragama/berkeyakinan. Di antara tradisi filosofis itu adalah tradisi filsafat liberalisme dan eksistensialisme. Kedua tradisi ini sangat kuat mendukung prinsip kebebasan, termasuk kebebasan beragama/berkeyakinan. Dalam tradisi eksistensialisme, Kierkegaard (18131855) dan Karl Jaspers (1883-1969) telah mengemukakan argumen-argumen filosofis untuk memberikan landasan bagi kebebasan beragama/

\footnotetext{
1 Menurut Ian Shapiro, untuk memahami konsep hak, kita perlu membedah serangkaian konsep moral dan politik yang bersifat formal dan relasional yang terdiri dari empat pernyataan: subjek hak, substansi hak, tujuan hak, dan landasan hak. Dengan demikian, ketika berbicara tentang apa itu hak, maka kita bisa bertanya: siapa yang berhak? Berhak untuk apa? Untuk tujuan apa? Atas dasar apa? Sejauh ini, pembahasan tentang landasan terkait hak atas kebebasan beragama/berkeyakinan belum terlalu banyak dikemukakan secara baik. Lih. Ian Shapiro, Evolusi Hak dalam Teori Liberal, terj. Marsi Maris (Jakarta: Yayasan Obor Indonesia, 2006), 15.
} 
berkeyakinaan sebagai bagian dari kebebasan manusia. Dalam tradisi filsafat liberal, John Locke (1632-1704) dan Immanuel Kant (1724-1804) juga telah banyak mengemukakan argumen-argumen tentang otonomi individu untuk mendukung kebebasan beragama/berkeyakinan. ${ }^{2}$

Dalam makalah ini, saya akan memfokuskan pembahasan pada argumentasi-argumentasi filsafat kontemporer yang bisa dijadikan landasan moral bagi normativitas hak atas kebebasan beragama/berkeyakinan (KBB). ${ }^{3}$ Secara khusus, pembahasan dalam makalah ini diarahkan pada dua argumentasi filsafat yang bisa dipakai untuk memberikan pendasaran terhadap KBB: Teori Keadilan dari John Rawls dan Teori Kepemilikan-Diri dari Robert Nozick. Kedua argumentasi filosofis ini tidak saja bisa mendasari normativitas hak atas $\mathrm{KBB}$, melainkan juga bisa menjelaskan mengapa KBB kategori forum internum tidak bisa dibatasi karena alasan apapun, sementara ketegori forum eksternum bisa dibatasi atau dikurangi.

Makalah ini disusun dengan sistematika sebagai berikut. Bagian II “Hak atas Kebebasan Beragama/Berkeyakinan” berisi pembahasan tentang KBB dalam instrumen-instrumen hak-hak asasi manusia. Kemudian, bagian III "Prinsip-prinsip Implementasi dan Kemungkinan Pembatasannya" menjelaskan beberapa interpretasi praktis bagi penerapan dan pembatasan hak atas KBB. Kemudian, pada bagian IV “Argumen Keadilan” dijelaskan pendasaran bagi hak atas KBB dengan menggunakan landasan Teori Keadilan John Rawls. Selanjutnya, Bagian V "Argumen Kepemilikan-Diri" berisi upaya pendasaran bagi hak atas KBB dengan menggunakan landasan Teori Kepemilikan-Diri Robert Nozick. Makalah ini diakhiri dengan sebuah Catatan Penutup.

2 Pembahasan tentang argumen-argumen Locke, Kierkegaard, dan Kant bisa dilihat dalam F. Budi Hardiman, Filsafat Modern: Dari Machiavelli sampai Nietzsche (Jakarta: Gramedia, 2004). Tentang Jaspers, bisa dilihat dalam K. Bertents, Filsafat Barat Abad XX: Inggris-Jerman (Jakarta: Gramedia, 1990), 127- 40.

3 Untuk selanjutnya, istilah kebebasan beragama/berkeyakinan dalam makalah ini akan disebut KBB saja. 
Hak Atas Kebebasan Beragama dan Berkeyakinan

Apa yang dimaksud dengan hak atas kebebasan beragama dan berkeyakinan? Cara yang bagus untuk menjawab pertanyaan ini, menurut hemat saya, adalah dengan melihat kembali bagaimana intstrumeninstrumen Hak-hak Asasi Manusia (HAM) menjelaskan apa itu kebebasan beragama/berkeyakinan (KBB). Sebab, instrumen-instrumen HAM itu sendiri merupakan hasil konsensus bangsa-bangsa di seluruh dunia melalui berbagai diskusi dan sidang di Majelis Umum Perserikatan Bangsa-bangsa (PBB). Karenanya, definisi dan penjelasan tentang kebebasan beragama/berkeyakinan sebagaimana termaktub di dalam instrumeninstrumen HAM tersebut telah berlaku umum dan disepakati oleh banyak pihak.

Pertama, KBB dalam Deklarasi Universal Hak Asasi Manusia (DUHAM). DUHAM adalah wujud nyata komitmen bangsa-bangsa di dunia untuk penegakan HAM. DUHAM menegaskan bahwa semua hak-hak yang ada di dalam DUHAM tersebut bisa dinikmati oleh semua orang tanpa membeda-bedakan agama dan keyakinan yang dianutnya. Secara khusus, Pasal 18 DUHAM menyatakan perihal kebebasan beragama atau berkeyakinan sebagai berikut:

Setiap orang berhak atas kebebasan pikiran, hati nurani dan agama; hak ini mencakup kebebasan untuk mengubah agama atau kepercayaan, dan kebebasan untuk manjalankan agama atau kepercayaannya dalam pengajaran, praktik, ibadat, dan kekhidmatan, baik sendiri maupun bersamasama dengan orang lain, di muka umum maupun sendiri. ${ }^{4}$

Kedua, KBB dalam Kovenan Internasional Hak Sipil dan Politik. Pasal 18 Kovenan Internasional Hak Sipil dan Politik menyatakan prihal KBB sebagai berikut: ${ }^{2}$

4 Lih. Frans Ceunfin (ed.), Hak-hak Asasi Manusia: Pendasaran dalam Filsafat Hukum dan Filsafat Politik Jilid 1 (Maumere: Penerbit Ledalero, 2007), 32.

5 Ceunfin (ed.), Hak-hak Asasi Manusia, 47. 
1. Setiap orang berhak atas kebebasan berpikir, keyakinan dan beragama. Hak ini mencakup kebebasan untuk menetapkan agama atau kepercayaan atas pilihannya sendiri, dan kebebasan, baik sendiri maupun bersama-sama dengan orang lain, baik di tempat umum atau tertutup, untuk menjalankan agama dan kepercayaannya dalam kegiatan ibadah, penataan, pengamalan dan pengajaran.

2. Tidak seorang pun dapat dipaksa sehingga terganggu kebebasannya untuk menganut atau menetapkan agama atau kepercayaannya sesuai dengan pilihannya.

3. Kebebasan menjalankan dan menentukan agama atau kepercayaan seseorang hanya dapat dibatasi oleh ketentuan berdasarkan hukum, dan yang diperlukan untuk melindungi keamanan, ketertiban, kesehatan, atau moral masyarakat, atau hak-hak dan kebebasan dasar orang lain.

4. Negara Pihak dalam Kovenan ini berjanji untuk menghormati kebebasan orang tua, dan apabila diakui, wali hukum yang sah, untuk memastikan bahwa pendidikan agama dan moral bagi anak-anak mereka sesuai dengan keyakinan mereka sendiri.

Kovenan Internasional Hak Sipil dan Politik Pasal 20 ayat 2 juga berbicara soal KBB. Pasal 20 ayat 2 tersebut menyatakan perihal larangan untuk perang dan tindakan yang menganjurkan kebencian atas dasar agama sebagai berikut: ${ }^{6}$

Segala tindakan yang menganjurkan kebencian atas dasar kebangsaan, ras atau agama yang merupakan hasutan untuk melakukan diskriminasi, permusuhan atau kekerasan, harus dilarang oleh hukum.

Ketiga, KBB dalam Deklarasi Penghapusan Segala Bentuk Intoleransi dan Diskriminasi Berdasarkan Agama. Deklarasi ini menjelaskan ihwal cakupan KBB sebagai berikut: ${ }^{7}$

6 Ceunfin (ed.), Hak-hak Asasi Manusia, 48.

7 Iqbal Hasanuddin (ed.), Membela Kebebasan Beragama/Berkeyakinan (Jakarta: LSAF, 2013), 66. 
1. Beribadah atau berkumpul dalam hubungannya dengan suatu agama atau kepercayaan, dan mendirikan serta mengelola tempat-tempat untuk tujuan-tujuan ini;

2. Mendirikan dan mengelola berbagai lembaga amal atau kemanusiaan yang sesuai;

3. Membuat, memperoleh dan mempergunakan secukupnya perlengkapan dan bahan-bahan yang diperlukan berkaitan dengan upacara atau adatistiadat suatu agama atau kepercayaan;

4. Menulis, menerbitkan dan menyebarluaskan berbagai penerbitan yang relevan di bidang ini;

5. Mengajarkan suatu agama atau kepercayaan di tempat-tempat yang sesuai untuk tujuan-tujuan ini;

6. Mengumpulkan dan menerima sumbangan-sumbangan keuangan dan sumbangan-sumbangan lain secara sukarela dari perseorangan atau lembaga;

7. Melatih, menunjuk, memilih atau mencalonkan melalui suksesi para pemimpin yang tepat yang diperlukan berdasarkan persyaratanpersyaratan dan standar-standar agama atau kepercayaan apapun;

8. Menghormati hari-hari istirahat dan merayakan hari-hari libur dan upacara-upacara menurut ajaran-ajaran agama atau kepercayaan seseorang;

9. Mendirikan dan mengelola komunikasi-komunikasi dengan seseorang dan masyarakat dalam persoalan-persoalan agama atau kepercayaan pada tingkat nasional dan internasional.

Prinsip-prinsip Implementasi dan Syarat-syarat Kemungkinan bagi Pembatasannya

Berdasarkan analisis atas instrumen-instrumen HAM internasional tentang hak atas KBB di atas, pada bagian ini saya mencoba menguraikan prinsip-prinsip implementasi dan kemungkinan pembatasan atasnya. Kedua 
hal ini merupakan upaya untuk menginterpretasi instrumen-instrumen tersebut dalam kerangka yang bersifat praktis yang terdiri dari ulasan atas definisi agama dan keyakinaan dalam KBB serta kategori forum internum dan forum eksternum sebagai dua dimensi KBB.

Pertama, definisi agama dan keyakinana dalam KBB. Di dalam instrumen-instrumen HAM tersebut, agama atau keyakinan tidak didefinisikan secara kaku serta tidak secara khusus mengacu kepada agamaagama formal yang terlembaga. Bahkan, istilah agama dan keyakinan di dalam instrumen-instrumen HAM bisa saling dipertukarkan satu sama lain. Sebab, istilah agama dan kepercayaan di dalam instrumen-instrumen HAM di atas meliputi juga keyakinan untuk tidak bertuhan (atheistic), non-tuhan (non-theistic), bertuhan (theistic). ${ }^{8}$

Definisi agama atau keyakinan dalam instrumen-instrumen HAM ini bersifat longgar, karena KBB tersebut pada dasarnya merupakan bagian dari kebebasan berpikir dan kebebasan suara hati. Ini bisa dimengerti mengapa KBB disatukan dalam Pasal 18 DUHAM. Secara lebih umum, KBB dalam HAM adalah perwujudan dari penghargaan terhadap martabat manusia sebagai person moral yang rasional, bebas dan setara. ${ }^{9}$

Kedua, hak atas KBB memiliki dua dimensi: forum internum dan forum eksternum. Di sini, forum internum adalah KBB yang berada dalam pikiran atau kesadaran seseorang, sementara forum eksternum adalah KBB yang sudah termanifestasi keluar, baik dalam sikap dan tindakan seseorang. Dimensi internum dari KBB meliputi kebebasan berpikir, berkeyakinan, dan beragama. Hak ini mencakup kebebasan setiap orang untuk memiliki, menganut, mempertahankan atau pindah agama/keyakinan. Sementara dimensi eksternum dari KBB meliputi kebebasan setiap orang, baik sendiri maupun bersama-sama dengan orang lain, di tempat umum atau wilayah

\footnotetext{
8 Hasanuddin (ed.), Membela Kebebasan Beragama/Berkeyakinan, 74.

9 Tentang hal ini, lih. Franz Magnis-Suseno, Etika Politik: Prinsip-prinsip Moral Dasar Kenegaraan Modern (Jakarta: Gramedia, 2003), 146-56.
} 
pribadi, untuk memanifestasikan agama atau kepercayaannya di dalam pengajaran, pengalaman, ibadah dan penataannya. ${ }^{10}$

Pembedaan dimensi internum dan eksternum dari KBB ini sangat penting dalam menentukan apakah implementasi KBB itu bisa dibatasi atau tidak. Karena itu, ulasan tentang mana saja KBB yang masuk ke dalam forum internum dan mana yang masuk forum eksternum menjadi sangat penting. The Indonesian Legal Resource Center (ILRC) membagi dua dimensi KBB tersebut ke dalam bagan sebagai berikut: ${ }^{11}$

\begin{tabular}{|c|c|}
\hline Forum Internum & Forum Eksternum \\
\hline $\begin{array}{l}\text { 1. Hak untuk menganut agama } \\
\text { atau keyakinan tertentu } \\
\text { berdasarkan pilihannya } \\
\text { sendiri; } \\
\text { 2. Hak untuk memiliki atau } \\
\text { melakukan penafsiran } \\
\text { keagamaan; } \\
\text { 3. Hak untuk berpindah } \\
\text { agama. }\end{array}$ & $\begin{array}{l}\text { 1. Hak untuk melakukan kegiatan } \\
\text { ritual seperti ibadah/sembahyang, } \\
\text { atau upacara keagamaan, baik } \\
\text { secara pribadi maupun bersama- } \\
\text { sama, baik secara tertutup } \\
\text { maupun terbuka; } \\
\text { 2. Hak untuk mendirikan tempat } \\
\text { ibadah; } \\
\text { 3. Hak untuk memungut iuran } \\
\text { keagamaan; }\end{array}$ \\
\hline
\end{tabular}

10 Kovenan Internasional Hak Sipil dan Politik Pasal 18 menyatakan ruang lingkup KBB sebagai "Setiap orang berhak atas kebebasan berpikir, keyakinan, dan beragama. Hak ini mencakup kebebasan untuk menetapkan agama atau kepercayaan atas pilihannya sendiri, dan kebebasan, baik sendiri maupun bersama-sama dengan orang lain, baik di tempat umum atau wilayah pribadi, untuk menjalankan agama dan kepercayaannya dalam kegiatan ibadah, pentaatan, pengamalan dan pengajaran." Di sini, KBB bisa dijalankan baik secara sendiri-sendiri maupun berkelompok, serta di tempat umum maupun wilayah pribadi. Di sini, KBB bisa dijalankan baik secara sendiri-sendiri maupun berkelompok, serta di tempat umum maupun wilayah pribadi. Tentang hal ini, lih. Ceunfin (ed.), Hak-hak Asasi Manusia, h. 47; lih. juga Tore Lindholm, W. Cole Durham, Jr. Bahia G. Tahzib-Lie (ed), Kebebasan Beragama atau Berkeyakinan: Seberapa Jauh? Sebuah Referensi tentang Prinsip-prinsip dan Praktik (Yogyakarta: Kanisius, 2010), 19-21. 11 Pultoni, Siti Aminah, Uli Parulian Sihombing, Panduan Pemantauan Tindak Pidana Penodaan Agama dan Ujaran Kebencian atas Dasar Agama (Jakarta: The Indonesian Legal Resources Center, 2012), 16. 


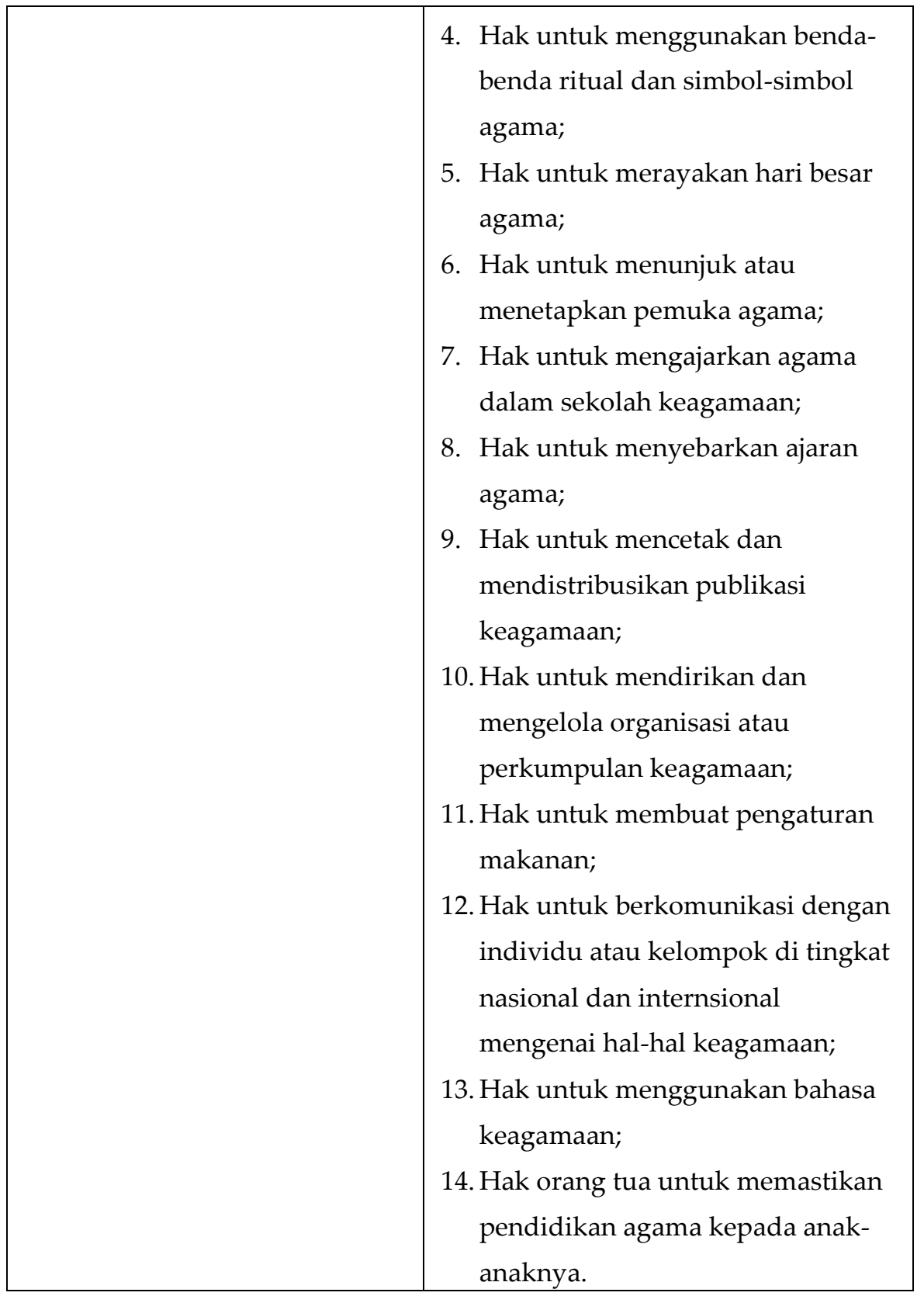

Hak atas KBB yang termasuk ke dalam kategori forum internum di atas bersifat mutlak dimiliki oleh setiap manusia tanpa terkecuali. Dengan kata lain, setiap orang harus dihormati haknya untuk menganut agama atau 
keyakinan tertentu berdasarkan pilihannya sendiri, hak untuk memiliki atau melakukan penafsiran keagamaan, dan hak untuk berpindah agama. Hak ini dimiliki oleh setiap orang tanpa memandang perbedaan suku, warna kulit, jenis kelamin, bahasa, agama/keyakinan, orientasi politik atau perbedaan pendapat, kebangsaaan atau asal-usulnya, tingkat kekayaan, kelahiran atau status-status lainnya. Inilah yang disebut sebagai prinsip nondiscrimination (tidak diskriminatif) dalam beragama/berkeyakinan. ${ }^{12}$

Selain itu, hak atas KBB yang termasuk ke dalam kategori forum internum ini juga tidak boleh dikurangi atau dibatasi atas dasar alasan apapun. Dengan kata lain, setiap orang harus dihormati haknya untuk menganut agama atau keyakinan tertentu berdasarkan pilihannya sendiri, hak untuk memiliki atau melakukan penafsiran keagamaan, dan hak untuk berpindah agama. Hak-hak ini tidak bisa dikurangi atau dibatasi. Inilah yang disebut sebagai prinsip non-derogability (tak dapat dikurangi) dalam beragama/berkeyakinan. ${ }^{13}$

Selain itu, hak atas KBB yang termasuk ke dalam kategori forum internum ini tidak boleh dipaksa atas dasar alasan apapun. Dengan kata lain, tidak ada seorang pun yang dapat dipaksa sehingga terganggu kebebasannya untuk menganut agama atau keyakinan tertentu berdasarkan pilihannya sendiri, hak untuk memiliki atau melakukan penafsiran keagamaan, dan hak untuk berpindah agama. Inilah yang sering disebut sebagai prinsip non-coercion (tak ada paksaan) dalam beragama/berkeyakinan. ${ }^{14}$

Berbeda dengan dimensi forum internum di atas, hak atas KBB yang termasuk ke dalam kategori forum eksternum ini dapat dibatasi dengan syarat-syarat sebagai berikut: (1) diatur oleh undang-undang; dan (2) jika memang benar-benar diperlukan untuk melindungi kesehatan umum,

\footnotetext{
12 Lindholm, Durham, \& Tahzib-Lie (ed), Kebebasan Beragama atau Berkeyakinan, 19-21.

13 Ibid.

14 Ibid.
} 
keselamatan umum, ketertiban umum, moral umum, atau hak-hak dan kebebasan dasar orang lain. ${ }^{15}$

Apa yang dimaksud dengan pernyataan bahwa hak atas KBB yang termasuk ke dalam kategori forum eksternum dapat dibatasi dengan syarat diatur oleh undang-undang? Maksudnya adalah bahwa pembatasan terhadap hak atas KBB hanya diperbolehkan jika pembatasan itu dibuat melalui proses legislasi. Dalam hal ini, presiden, menteri, gubernur, bupati/walikota, camat, lurah/kepala desa, atau aparat kepolisian tidak bisa mengeluarkan suatu peraturan secara sepihak untuk membatasi hak atas KBB. Proses legislasi untuk membuat pembatasan ini harus dilakukan dengan melibatkan parlemen dan pemerintah. Selain itu, proses dan substansi dari legislasi tersebut harus betul-betul memperhatikan kaidahkaidah dan semangat yang tidak bertentangan dengan prinsip-prinsip dan nilai-nilai yang terkandung di dalam HAM secara keseluruhan. ${ }^{16}$

Apa yang dimaksud dengan pernyataan bahwa hak atas KBB yang termasuk ke dalam kategori forum eksternum dapat dibatasi jika memang benar-benar diperlukan untuk melindungi kesehatan umum, keselamatan umum, ketertiban umum, moral umum, atau hak-hak dan kebebasan dasar orang lain? Ini berarti bahwa jika hak atas KBB yang termasuk ke dalam kategori forum eksternum mau dibatasi, maka pembatasan itu hanya boleh dilakukan untuk lima alasan berikut. ${ }^{17}$

Pertama, pembatasan dilakukan jika manifestasi keagamaan/keyakinan seseorang atau sekelompok orang berpotensi mengancam kesehatan orang lain. Kedua, pembatasan dilakukan jika manifestasi keagamaan/keyakinan seseorang atau sekelompok orang berpotensi mengancam keamanan (nyawa dan fisik) orang lain. Ketiga, pembatasan dilakukan jika manifestasi keagamaan/keyakinan seseorang atau sekelompok orang berpotensi misalnya melanggar lalu-lintas jalan di

15 Pultoni dkk., Panduan Pemantauan Tindak Pidana Penodaan Agama dan Ujaran Kebencian atas Dasar Agama, 21-2.

16 Ibid., 21.

17 Ibid., 22. 
sekitarnya. Keempat, pembatasan dilakukan jika manifestasi keagamaan/keyakinan seseorang atau sekelompok orang mensyaratkan kepada anggotanya untuk misalnya meminum racun, memakan mayat atau membunuh manusia. Dan kelima, pembatasan dilakukan jika manifestasi keagamaan/keyakinan seseorang atau sekelompok orang berpotensi mengancam hak-hak dasar orang lain seperti hak untuk hidup atau hak untuk tidak disiksa. ${ }^{18}$

\section{Argumen Keadilan}

Persoalan-persoalan filosofis yang harus dijawab terkait hak atas KBB sebagaimana ditampilkan di dalam instrumen-instrumen HAM di atas adalah: Pertama, mengapa KBB setiap orang harus dihargai dan dilindungi? Kedua, KBB dalam kategori forum internum tidak boleh dikurangi atau dibatasi karena alasan apapun dan dalam keadaan apapun? Ketiga, mengapa KBB dalam kategori forum eksternum boleh dibatasi atau dikurangi dengan syarat-syarat (1) diatur oleh undang-undang; dan (2) jika memang benarbenar diperlukan untuk melindungi kesehatan umum, keselamatan umum, ketertiban umum, moral umum, atau hak-hak dan kebebasan dasar orang lain?

Ketiga persoalan filosofis terkait hak atas KBB tersebut akan coba dijawab dengan mengemukakan dua argumen dua orang filsuf kontemporer: John Rawls dan Robert Nozick. Melalui Teori Keadilan yang dirumuskannya, Rawls melihat penghargaan dan perlindungan terhadap hak atas KBB sebagai perwujudan penghargaan dan perlindungan terhadap martabat manusia sebagai person moral yang rasional, bebas dan setara satu sama lain. Sementara itu, Nozick tidak secara khusus berbicara tentang KBB. Dalam makalah ini, saya akan memanfaatkan Teori Kepemilikan-Diri yang

18 Ibid., 22-3. 
dirumuskan oleh Nozick untuk dijadikan landasan bagi pembelaan terhadap KBB.

\section{Keadilan sebagai Fairness}

Dalam A Theory of Justice (1971), John Rawls mencoba manjawab persoalan: Apa yang memungkinkan anggota-anggota dari suatu masyarakat secara bersama-sama menerima dan mematuhi ketentuanketentuan sosial yang mengatur pembagian hak dan kewajiban di antara mereka? Apa yang bisa mendorong anggota-anggota masyarakat tersebut untuk terlibat secara sukarela dalam berbagai kerja sama sosial? ${ }^{19}$ Terhadap pertanyaan-pertanyaan ini, Rawls mengemukakan bahwa kesukarelaan segenap anggota masyarakat untuk menerima dan mematuhi ketentuanketentuan sosial yang ada hanya dimungkinkan jika masyarakatnya tertata baik di mana keadilan sebagai fairness menjadi dasar bagi prinsip-prinsip pengaturan institusi-institusi yang ada di dalamnya. ${ }^{20}$

Sampai di sini, pertanyaan belum sepenuhnya terjawab. Lantas, apa yang Rawls maksudkan dengan keadilan sebagai fairness? Ketika berbicara tentang ketentutan-ketentuan sosial yang mengatur kehidupan bersama, Rawls sebenarnya sedang menekankan upaya untuk merumuskan prinsipprinsip yang mengatur distribusi hak dan kewajiban di antara segenap anggota suatu masyarakat. Agar distribusi hak dan kewajiban bisa terjamin dengan baik, Rawls menekankan pentingnya kesepakatan yang fair di antara semua anggota masyarakat, karena hanya kesepakatan fair yang mampu mendorong kerja sama sosial. ${ }^{21}$

Masalahnya, bagaimana kesepakatan yang fair itu bisa diperoleh? Rawls memandang bahwa kesepakatan yang fair hanya bisa dicapai dengan adanya prosedur yang tidak memihak. Dalam hal ini, apa yang dibutuhkan oleh mereka yang terlibat dalam proses perumusan konsep keadilan

\footnotetext{
19 John Rawls, A Theory of Justice (London: Oxford University Press, 1971), 4-5.

20 Ibid.

21 Ibid.
} 
hanyalah suatu prosedur yang fair (tidak memihak) untuk menjamin hasil akhir yang adil pula. ${ }^{22}$

Bagi Rawls, prosedur yang fair ini hanya bisa terpenuhi apabila terdapat iklim musyawarah yang memungkinkan lahirnya keputusan yang mampu menjamin distribusi yang fair atas hak dan kewajiban. Rawls menegaskan pentingnya semua pihak, yang terlibat dalam proses musyawarah untuk memilih prinsip-prinsip keadilan, berada dalam suatu kondisi awal yang disebutnya "posisi asali" (the original position). ${ }^{23}$

Rawls menegaskan bahwa semua pihak yang berada dalam posisi asali harus juga berada dalam keadaan "tanpa pengetahuan." Melalui gagasan tentang "keadaan-tanpa-pengetahuan" tersebut, Rawls ingin menegaskan bahwa semua pihak yang ada dalam posisi asali tidak memiliki pengetahuan mengenai berbagai alternatif yang dapat mempengaruhi mereka dalam proses perumusan dan pemilihan prinsip-prinsip pertama keadilan. Keadaan ketidaktahuan akan hal-hal partikular memang menjadi syarat penting untuk menjamin fairness. Oleh karena itu, semua pihak yang terlibat dalam proses pemilihan tersebut harus mampu melakukan penilaian atas prinsip-prinsip keadilan yang senantiasa dipandu oleh pertimbanganpertimbangan yang umum sifatnya. ${ }^{24}$

Dalam kondisi awal (posisi asali) sebagaimana dijelaskan di atas, Rawls percaya bahwa semua pihak akan bersikap rasional; dan sebagai person yang rasional, semua pihak akan lebih suka memilih prinsip keadilan yang ditawarkannya sebagai berikut:

Semua nilai-nilai sosial-kebebasan dan kesempatan, pendapatan dan kekayaan, dan basis harga diri-harus didistribusikan secara sama. Suatu distribusi yang tidak sama atas nilai-nilai sosial tersebut hanya diperbolehkan

22 Ibid.

23 Ibid., 120.

24 Ibid., 136-42. 
apabila hal itu memang menguntungkan orang-orang yang paling tidak beruntung. ${ }^{25}$

Bertolak dari prinsip umum di atas, Rawls merumuskan kedua prinsip keadilan sebagai berikut: 1. Setiap orang harus memiliki hak yang sama atas kebebasan dasar yang paling luas, seluas kebebasan yang sama bagi semua orang; 2. Ketidaksamaan sosial ekonomi harus diatur sedemikian rupa sehingga (a) diharapkan memberi keuntungan bagi bagi orang-oang yang paling tidak beruntung, dan (b) semua posisi dan jabatan terbuka bagi semua orang. ${ }^{26}$

Dalam dua prinsip keadilannya ini, Rawls menekankan bahwa hakhak serta kebebasan-kebebasan dasar tidak bisa ditukar dengan keuntungan-keuntungan sosial dan ekonomi. Hal ini berarti bahwa prinsip keadilan kedua hanya bisa mendapat tempat dan diterapkan apabila prinsip keadilan pertama telah terpenuhi. Dengan kata lain, penerapan dan pelaksanaan prinsip keadilan yang kedua tidak boleh bertentangan dengan prinsip keadilan yang pertama. Oleh karena itu, hak-hak dan kebebasankebebasan dasar dalam konsep keadilan khusus ini memiliki prioritas utama atas keuntungan-keuntungan sosial dan ekonomi. ${ }^{27}$ Bagi Rawls, pembatasan terhadap hak dan kebebasan hanya diperbolehkan sejauh hal itu dilakukan demi melindungi dan mengamankan pelaksanaan kebebasan itu sendiri. Itu berarti, perlu diterima suatu pengaturan secara kelembagaan atas praktekpraktek kebebasan agar pelaksanaan kebebasan tidak membahayakan kebebasan yang memang menjadi hak setiap orang.

\section{KBB Harus Dihormati dan Dilindungi}

Mengapa KBB harus dihormati dan dilindungi? Jika kita semua berada di dalam posisi asali sebagaimana dirumuskan oleh Rawls, maka kita tidak akan membiarkan disepakatinya suatu prinsip yang membolehkan

\footnotetext{
25 Ibid., 62.

26 Ibid., 60.

27 Ibid., 250.
} 
hak atas KBB untuk dilanggar. Sebab, dalam posisi asali, kita tidak tahu tentang agama/keyakinan apa yang akan kita anut. Kita juga tidak tahu apakah agama/keyakinan yang akan kita anut itu akan berada dalam posisi dominan atau marjinal. Karena kita sangat mungkin nantinya menganut suatu agama/keyakinan yang berada dalam posisi marjinal, maka kita tidak akan membiarkan diskriminasi dijadikan sebagai prinsip dasar penataan masyarakat.

Demikian, dalam kerangka Teori Keadilan yang dirumuskan oleh Rawls, kita dapat dengan mudah menempatkan KBB sebagai salah satu kebebasan dasar dalam Prinsip Pertama dari Teori Keadilan. Dengan demikian, setiap manusia pada dasarnya ingin agar hak atas KBB dihargai dan dilindungi. Pelanggaran terhadap hak atas KBB seseorang berarti telah mengingkari posisi orang itu sebagai person moral yang rasional, bebas dan setara. Sebaliknya, pengakuan atas hak seseorang atas KBB berarti telah menghargainya sebagai person moral yang rasional, bebas dan setara. Dalam konteks inilah, KBB adalah bagian dari hak-hak manusia yang bersifat fundamental.

Dalam hal ini, sebuah negara yang tidak menghargai dan melindungi hak atas KBB, maka negara itu bukanlah sebuah negara yang adil. Salah satu ukuran tegaknya keadilan di dalam suatu negara adalah ada atau tidaknya penghargaan dan perlindungan terhadap hak atas KBB. Jika keadilan di dalam sebuah negara tidak ditegakkan karena tidak dihargai dan dilindunginya hak atas KBB tersebut, maka akan sulit diharapkan terciptanya kerja sama yang fair di antara segenap warga.

\section{KBB dalam Kategori Forum Eksternum Boleh Dibatasi}

$\mathrm{KBB}$, sebagaimana kebebasan pada umumnya, dapat dibatasi dengan alasan untuk kepentingan umum, keteraturan, dan perlindungan 
masyarakat. Menurut John Rawls, pembatasan ini harus dibangun berdasarkan beberapa catatan: ${ }^{28}$

1. Penerimaan terhadap pembatasan ini tidak membuktikan bahwa kepentingan publik lebih unggul dibanding kepentingan religius dan moral;

2. Tidak pula mengharuskan bahwa pemerintah memandang persoalanpersoalan religius merupakan perkara biasa saja atau mengklaim hak untuk menindas keyakinan-keyakinan filosofis ketika semua itu dipandang berbenturan dengan urusan negara.

Dalam pandangan Rawls, negara tidak mengurusi doktrin religius dan filosofis, tapi mengatur usaha individu-individu dalam mengejar kepentingan moral dan spiritual mereka sesuai dengan prinsip-prinsip yang akan mereka setujui dalam situasi kesetaraan. Dalam hal ini pemerintah bertindak sebagai agen warga negara dan memuaskan tuntutan-tuntutan konsepsi publik mereka tentang keadilan. Pemerintah tidak mempunyai hak dan kewajiban untuk melakukan apa yang ingin dilakukan atau diinginkan oleh mayoritas (apapun) dalam permasalahan moral dan agama. Tugas negara terbatas pada menjamin terciptanya kondisi-kondisi kebebasan moral dan religius yang setara. ${ }^{29}$

KBB dapat dibatasi hanya ketika ada dugaan yang masuk akal bahwa kalau tidak melakukan pembetasan maka hal itu akan menghancurkan keteraturan publik yang harus ditegakan oleh pemerintah. Dugaan ini harus didasarkan pada bukti dan cara berpikir yang diterima oleh semua orang. Dugaan harus didukung oleh metode observasi dan cara-cara pemikiran (termasuk metode-metode penyelidikan ilmiah yang bersifat rasional) yang secara umum diakui sebagai benar. Intinya, pembatasan KBB diperbolehkan hanya ketika hal itu perlu bagi kebebasan itu sendiri, untuk mencegah terjadinya pelanggaran kebebasan yang akan lebih buruk lagi. ${ }^{30}$

\footnotetext{
28 Ibid., 207-8.

29 Ibid., 202-3.

30 Ibid., 203-4.
} 


\section{Argumen Kepemilikan-Diri}

Dalam Anarchy, State and Utopia, Nozick berupaya untuk merekonstruksi prinsip Kant yang menyatakan bahwa "kita harus senantiasa memperlakukan manusia sebagai tujuan, bukan sebagai sarana," menjadi prinsip "kepemilikan-diri". Bagi Nozick, prinsip "memperlakukan orang sebagai tujuan", yang digunakan oleh Kant untuk menyatakan persamaan moral semua individu, niscaya akan menghasilkan prinsip "kepemilikan-diri". ${ }^{11}$ Sebab, jika ditanya, mengapa kita harus memperlakukan setiap manusia senantiasa sebagai tujuan? Maka jawabannya adalah, kerena setiap manusia adalah milik dirinya sendiri. Jika kita menjadikan seorang manusia sebagai sarana untuk tujuan-tujuan kita, maka itu artinya kita telah menjadikan manusia itu sebagai milik kita. Bukankah hanya harta benda yang bisa dijadikan sarana untuk tujuantujuan yang punya harta benda itu? Jika kita memperlakukan orang lain sebagai sarana, maka itu sama saja kita membuat orang itu sama dengan benda. Ketika itu terjadi, maka orang itu sudah tidak memiliki dirinya sendiri.

\section{Kepemilikan-Diri}

Kalimat pertama dari buku Anarchy, State and Utopia yang ditulis oleh Nozick menyatakan bahwa 'Individu memiliki hak, dan ada hal-hal yang tidak seorang atau kelompok pun bisa mencampurinya (tanpa melanggar hak-haknya). ${ }^{32}$ Menurut Nozick, masyarakat harus menghormati hak-hak ini, karena penghormatan atas hak-hak ini merefleksikan prinsip Kantian yang menyatakan bahwa setiap individu senantiasa merupakan tujuan,

31 Robert Nozick, Anarchy, State, and Utopia (Oxford: Blackwell, 1974), 30-1.

32 Ibid., ix. 
bukan sarana; individu-individu tidak boleh dikorbankan atau dimanfaatkan untuk mencapai tujuan-tujuan lain tanpa persetujuannya. ${ }^{33}$

Lantas, karena manusia memiliki dirinya sendiri, maka segala hal terkait dirinya dan segala hal yang dihasilkan dirinya juga merupakan miliknya. Karena pesepak bola asal Argentina Lionel Messi memiliki dirinya, maka bakat dan kemampuan yang dia miliki dalam mengolah bola di lapangan hijau juga miliknya. Karena bakat dan kemampuan bermain bola itu miliknya, maka semua uang dan kekayaan yang dihasilkan dari bakat dan kemampuan bermain bola itu juga miliknya. Siapa pun tidak boleh mengambil uang atau kekayaan Messi dari hasil bermain bola tanpa persetujuan dari Messi. Jika ada orang yang mengambilnya tanpa persetujuan, maka orang itu dikatakan telah merampas hak Messi. ${ }^{34}$

Dalam alur argumentasi Nozick, jika negara mengambil sebagian uang dan kekayaan Messi tersebut untuk tujuan pengentasan kemiskinan orang-orang di kota kelahiran Messi di Argentina, tanpa persetujuan dari Messi, maka apa yang dilakukan oleh negara itu telah merampas hak Messi. Bahkan, berdasarkan kerangka kepemilikan-diri dari Nozick, jika negara memungut pajak yang tidak fair dari kekayaan Messi tanpa persetujuan Messi, maka itu sama saja negara telah memperbudak Messi. Sebab, jika negara mengambil uang Messi, itu artinya sama dengan negara telah meminta Messi bekerja tanpa bayaran, karena bayaran yang dihasilkan oleh Messi diambil oleh negara. Jika negara meminta Messi bekerja tanpa bayaran, maka itu sama saja dengan meminta Messi bekerja paksa. Jika negara meminta Messi untuk bekerja paksa, maka itu sama dengan mengingkari fakta bahwa Messi memiliki dirinya. Jika demikian, maka itu artinya negara mengklaim memiliki diri Messi. Lantas, pada akhirnya, itu berarti negara telah memperbudak Messi. ${ }^{35}$

\footnotetext{
33 Ibid., 30-1.

34 Contoh pesepak bola Leonel Messi adalah adaptasi dari tokoh Wilt Chamberlain yang digunakan oleh Nozick sendiri. Lih. Nozick, Anarchy, State, and Utopia, 160-2.

35 Ibid., 160-2.
} 
Dari kepemilikan-diri, Nozick kemudian berupaya untuk melegitimasi pasar bebas tanpa campur tangan negara. Sebab, menurut Nozick, hanya pasar besar yang bisa menghargai dan melindungi kepemilikan-diri setiap orang. Di dalam pasar bebas, setiap orang menggunakan uang dan kekayaan yang dihasilkan oleh dirinya untuk memperoleh apa yang dibutuhkannya. Mereka menggunakan uang dan kekayaaan di dalam pertukaran sukarela. Bahkan, jika seseorang menggunakan uang dan kekayaan yang dihasilkan oleh dirinya untuk membantu pengentasan kemiskinan orang-orang di sekitarnya secara sukarela, maka itu tidak melanggar prinsip kepemilikan-diri. ${ }^{36}$

Persoalannya adalah apakah setiap transaksi di dalam pasar bebas itu betul-betul hanya melibatkan uang dan kekayaan yang dihasilkan oleh diri orang yang yang bertransaksi tersebut? Kita ambil contoh orang yang melakukan jual-beli rumah. Apakah rumah yang dijual-belikan itu betulbetul secara murni dihasilkan oleh pemiliknya? Si pembuat atau pemilik itu memang memiliki dirinya ketika akan membuat rumah tersebut. Namun, apakah tanah dan batu-bata serta pasir itu dihasilkan oleh dirinya? Atas dasar apa ia merasa berhak untuk memanfaatkan tanah, batu-bata serta pasir untuk dijadikan rumah yang nantinya diakui sebagi miliknya itu? Orang mungkin mengatakan bahwa ia memperoleh tanah, batu-bata, pasir melalui transaksi jual-beli secara sukarela dari pemilik tanah sebelumnya. Tapi pertanyaannya adalah apakah pemilik tanah sebelumnya itu juga betul-betul berhak atas tanah itu? Katakan pemilik tanah sebelumnya itu mendapatkan tanah tersebut sebagai warisan sukarela dari orang tuanya. Pertanyaannya adalah bagaimana orang tuanya itu bisa memiliki tanah tersebut?

Pertanyaan seperti ini terus diajukan sampai pada pemilik tanah pertama. Ketika pertama kalinya diakui sebagai milik pribadi seseorang,

36 Ibid., 160-2. 
tanah itu tentu diasumsikan belum ada yang memiliki. Lantas, atas dasar apa si orang pertama itu merasa berhak memiliki tanah sebagai miliknya pribadi? Bukankah klaimnya atas tanah telah menghilangkan kesempatan orang lain untuk menggunakan atau memiliki tanah tersebut? Mungkin orang akan mengatakan bahwa siapa pun yang pertama kali mengklaim kepemilikan atas tanah yang tidak bertuan, maka dia sah menjadi pemiliknya. Pertanyaannya adalah kepada peraturannya demikian? Kenapa orang pertama yang menemukan tanah tak bertuan kemudian diperbolehkan menjadi pemiliknya?

Saya setuju dengan Will Kymlicka yang menilai bahwa Nozick berhasil untuk memberikan pendasaran filosofis atas kepemilikan-diri, namun dia gagal untuk melegitimasi kepemilikan terhadap properti yang melibatkan dunia eksternal di luar diri. Dengan kata lain, kepemilikan-diri memiliki keabsahan yang sulit untuk dibantah. Sementara itu, kepemilikan atas dunia eksternal di luar diri bersifat relatif, tidak seabsolut kepemilikandiri. Karena itu, jika kebebasan individu yang terkait dengan dirinya tidak boleh dibatasi karena alasan apapun, maka kebebasan indiviu terkait dunia eksternal tidak pernah benar-benar absolut. ${ }^{37}$

\section{KBB Dihormati dan Dilindungi}

Walaupun Nozick memaksudkan argumen kepemilikan-diri untuk melegitimasi kebebasan individu secara umum dan pasar bebas sebagai wahana sukarela untuk bertransaksi dari individu-individu yang samasama bebas, namun kita bisa memanfaatkan argumen kepemilikan-diri untuk menjustifikasi hak atas KBB. Dalam kerangka kepemilikan-diri yang dirumuskan oleh Nozick, kita bisa katakan bahwa karena setiap orang memiliki dirinya sendiri, maka setiap orang juga berhak atas apapun yang dia pikirkan, anut dan yakini. Karenanya, orang yang melanggar hak seseorang atas KBB berarti ia telah mengingkari fakta bahwa orang itu

37 Will Kymlicka, Contemporary Political Philosophy: An Introduction, Second Edition (Oxford: Oxford University Press, 2002), 110 \& 121. 
memiliki dirinya. Kemudian, itu berarti si pelanggar menganggap orang yang haknya dilanggar itu sebagai budak, karena orang itu sudah tidak memiliki hak lagi atas dirinya.

Sebaliknya, penghargaan dan perlindungan terhadap hak atas KBB sama dengan penghargaan dan perlindungan terhadap hak setiap orang atas dirinya sendiri. Ini sama dengan menghargai dan melindungi kepemilikan setiap orang atas dirinya sendiri. Ini sama dengan memperlakukan orang lain sebagai tujuan, dan tidak memperlakukan orang lain sebagai sarana. Lagi-lagi, penghargaan terhadap hak atas KBB adalah manifestasi dari penghargaan terhadap semua manusia sebagai person moral yang rasional, bebas dan setara.

\section{KBB dalam Kategori Forum Eksternum Boleh Dibatasi}

Bagaimana pembatasan terhadap KBB dalam kategori forum eksternum bisa dijelaskan di dalam kerangka teori kepemilikan-diri yang dirumuskan oleh Nozick? Sebagaimana telah dikemukakan, prinsip kepemilikan-diri bisa dibenarkan secara mutlak. Namun, kepemilikan seseorang terhadap dunia eksternal tidak bersifat mutlak. Misalnya, kepemilikan seseorang atas tanah dan bangunan tidak pernah benar-benar bersifat mutlak. Kepemilikan seseorang atas saluran udara dan atmosfir di atas bumi juga tidak pernah benar-benar mutlak.

Karena kepemilikan atas dunia eksternal tidak bisa bersifat mutlak, maka manifestasi keagamaan/keyakinan seseorang juga tidak pernah benarbenar bersifat mutlak. Walaupun seseorang menganggap bahwa sebidang tanah tempat bangunan ibadah adalah miliknya serta pengeras suara yang ada di tempat itu juga miliknya, itu tidak berarti ia bisa sesuka hati menyiarkan apa yang dianut atau diyakininya dengan menggunakan pengeras suara yang ada di tempat ibadahnya itu. Sebab, bukankah saluran udara tempat dilantunkannya ceramah-ceramah keagamaanya itu bukan 
miliknya? Itulah alasan mengapa penyiaran keagamaan di tempat publik bisa dibatasi.

Pembatasan atas manifestasi keagamaan/keyakinan seseorang yang dijalankan di tempat-tempat umum lebih bisa dibatasi lagi, karena manifestasi keagamaan/keyakinannya itu berpontensi melanggar hak orang lain untuk menggunakan tempat-tempat umum itu. Misalnya, meminta sumbangan untuk acara-acara keagamaan atau pembangunan tempat ibadah yang dilakukan di jalan-jalan umum berpotensi melanggar hak orang lain untuk bisa menggunakan jalan itu tanpa ada gangguan dari orang-orang yang tidak dikehendakinya.

Pembatasan atas manifestasi keagamaan/keyakinan seseorang jelasjelas bisa dibatasi jika manifestasi keagamaan/keyakinan tersebut melanggar hak orang lain atas kepemilikan-dirinya. Misalnya, upacara keagamaan yang mengancam keselamatan fisik dan nyawa jelas boleh dikurangi atau dibatasi. Atau, manifestasi keyakinan seseorang yang menimbulkan kehancuran sebuah kota jelas-jelas harus dibatasi atau dikurangi karena hal itu mengancam hak orang lain atas dirinya dan segala hal yang menjadi miliknya.

\section{Penutup}

\section{Rangkuman}

Dalam makalah ini, saya telah menguraikan apa itu KBB berdasarkan rumusan yang ada dalam instrumen-instrumen HAM internasional: Deklarasi Universal Hak-hak Asasi Manusia (DUHAM) Pasal 18, Kovenan Internasional Hak Sipil dan Politik Pasal 18, dan Deklarasi Penghapusan Segala Bentuk Intoleransi dan Diskriminasi Berdasarkan Agama. Ketiga instrumen HAM tentang KBB ini telah menjadi standar bagi bangsa-bangsa di dunia karena telah diputuskan dalam konsensus bersama dalam sidangsidang Majelis Umum PBB.

Berdasarkan ketiga instrumen di atas, prinsip-prinsip implementasi KBB dan syarat-syarat kemungkinan bagi pembatasannya juga telah ditetapkan bersama. Di antaranya yang utama adalah bahwa KBB dalam 
kategori forum internum atau penghayatan di dalam diri seseorang tidak bisa dikurangi atau dibatasi dengan alasan apapun. Dimensi forum internum KBB mencakup: haknya untuk menganut agama atau keyakinan tertentu berdasarkan pilihannya sendiri, hak untuk memiliki atau melakukan penafsiran keagamaan, dan hak untuk berpindah agama. Selain itu, KBB juga memiliki dimensi lain, yakni forum eksternum. Ini adalah dimensi KBB yang menyangkut manifestasinya keluar diri. Hak atas KBB yang termasuk ke dalam kategori forum eksternum ini dapat dibatasi dengan syarat-syarat sebagai berikut: (1) diatur oleh undang-undang; dan (2) jika memang benarbenar diperlukan untuk melindungi kesehatan umum, keselamatan umum, ketertiban umum, moral umum, atau hak-hak dan kebebasan dasar orang lain.

Meskipun KBB sebagai instrumen-instrumen HAM telah disepakai sebagai norma internasional dalam rapat-rapat Majelis Umum PBB, persoalan-persoalan filosofis yang harus tetap ada terkait hak atas KBB sebagaimana ditampilkan di dalam instrumen-instrumen HAM di atas adalah: Pertama, mengapa KBB setiap orang harus dihargai dan dilindungi? Kedua, mengapa KBB dalam kategori forum internum tidak boleh dikurangi atau dibatasi karena alasan apapun dan dalam keadaan apapun? Ketiga, mengapa KBB dalam kategori forum eksternum boleh dibatasi atau dikurangi dengan syarat-syarat (1) diatur oleh undang-undang; dan (2) jika memang benar-benar diperlukan untuk melindungi kesehatan umum, keselamatan umum, ketertiban umum, moral umum, atau hak-hak dan kebebasan dasar orang lain?

Di dalam makalah ini, saya menggunakan Teori Keadilan dari John Rawls dan Teori Kebebasan Libertarian dari Robert Nozick untuk memberikan pendasaran filosofis bagi hak atas KBB. Rawls dan Nozick sama-sama memanfaatkan prinsip yang dirumuskan oleh Kant yang menyatakan bahwa "manusia harus senantiasa dijadikan tujuan, tidak pernah boleh dijadikan sarana." Melalui Teori Keadilan yang dirumuskannya, Rawls melihat penghargaan dan perlindungan terhadap 
hak atas KBB sebagai perwujudan penghargaan dan perlindungan terhadap martabat manusia sebagai person moral yang rasional, bebas dan setara satu sama lain. Sementara itu, Nozick tidak secara khusus berbicara tentang KBB. Meskipun demikian, argumen kepemilikan-diri yang dirumuskannya merupakan argumen filosofis yang sangat kuat untuk melandasi pembelaan terhadap KBB. Teori Keadilan Rawls dan Teori Kepemilikan-Diri Nozick yang telah dimodifikasi terbukti bisa dipakai untuk menjelaskan mengapa hak atas KBB yang termasuk kategori forum internum tidak bisa dibatasi atau dikurangi atas dasar alasan apapun, sementara hak atas KBB yang termasuk kategori forum eksternum boleh dan bisa dibatasi.

\section{Relevansinya untuk Indonesia}

Dalam sistem hukum di Indonesia, instrumen-instrumen HAM terkait KBB telah diratifikasi sedemikian rupa sehingga menjadi bagian integral dari hukum nasional. Di antaranya adalah Undang-undang (UU) Republik Indonesia No.39 tahun 1999 tentang Hak-hak Asasi Manusia (HAM), khususnya pasal 22; juga UU No.12 tahun 2005 tentang pengesahan Kovenan Internasional Hak-hak Sipil dan Politik. Di samping kedua UU tersebut, Undang-undang Dasar (konstitusi) Indonesia juga sebenarnya telah memberikan jaminan yang kuat bagi hak atas KBB di Indonesia. ini bisa dilihat dalam UUD 1945 Pasal 28 (e) ayat 1 dan 2 yang menyebutkan bahwa: 1) Setiap orang bebas memeluk agama dan beribadat menurut agamanya, memilih pendidikan dan pengajaran, memilih pekerjaan, memilih kewarganegaraan, memilih tempat tinggal di wilayah negara dan meninggalkannya, serta berhak kembali; 2) Setiap orang berhak atas kebebasan meyakini kepercayaan, menyatakan pikiran dan sikap, sesuai dengan hati nuraninya. Ini masih diperkuat lagi oleh Pasal 29 ayat 2 yang nyatakan: Negara menjamin kemerdekaan tiap-tiap penduduk untuk memeluk agamanya masing-masing dan untuk beribadat menurut agama dan kepercayaannya itu. ${ }^{38}$

38 Hasanuddin (ed.), Membela Kebebasan Beragama/Berkeyakinan, 70. 
Meskipun jaminan hukum bagi hak atas KBB dalam sistem hukum di Indonesia sedemikian kuat, juga terdapat persoalan yang sampai sekarang masing menjadi dasar bagi praktik-praktik diskriminasi hak atas KBB. Persoalan yang saya maksudkan adalah keberadaan Undang-undang (UU) No.1/PNPS/1965 tentang Pencegahan, Penyalahgunaan dan/atau Penodaan Agama. ${ }^{39}$ Undang-undang inilah yang dipakai untuk mendiskriminasi kelompok penghayat kepercayaan dan penganut agama lokal serta kelompok-kelompok minoritas lainnya di Indonesia. Undang-undang ini juga sering dipakai sebagai alat untuk mengkriminalisasi praktik-praktik keaagamaan atau keyakinan yang dipandang berbeda dari praktik-praktik keagamaan atau keyakinan kelompok mayoritas.

Pada titik ini, syarat-syarat kemungkinan bagi pembatasan terhadap KBB sebagaimana dipaparkan dalam makalah ini bisa dipakai untuk menilai secara kritis apakah pembatasan atas KBB yang ada dalam sistem hukum di Indonesia sebagai sesuatu yang dapat dibenarkan. Dalam hal ini, apa yang

39 UU No.1/PNPS/1965 berbunyi sebagai berikut: (1) Pasal 1: Setiap orang dilarang dengan sengaja di muka umum menceritakan, menganjurkan, atau mengusahakan dukungan umum, untuk melakukan penafsiran tentang suatu agama yang dianut di Indonesia atau melakukan kegiatan-kegiatan keagamaan yang menyerupai kegiatan-kegiatan agama itu, penafsiran dan kegiatan mana menyimpang dari pokok-pokok ajaran dari agama itu; (2) Pasal 2: Barang siapa melanggar ketentuan tersebut dalam Pasal 1 diberi perintah dan peringatan keras untuk menghentikan perbuatannya itu di dalam suatu keputusan bersama Menteri Agama, Menteri/Jaksa Agung dan Menteri Dalam Negeri; (3) Pasal 3: Apabila, setelah dilakukan tindakan oleh Menteri Agama bersama-sama Menteri/Jaksa Agung dan Menteri Dalam Negeri atau oleh Presiden Republik Indonesia menurut ketentuan dalam Pasal 2 terhadap orang, organisasi, atau aliran keyakinan, mereka masih terus melanggar ketentuan dalam Pasal 1, maka orang, penganut, anggota dan/atau anggota pengurus organisasi yang bersangkutan dari aliran itu dipidana dengan pidana penjara selama-lamanya lima tahun; dan (4) Pasal 4: Pada Kitab Undang-undang Hukum Pidana diadakan pasal baru yang berbunyi sebagai berikut: Pasal 156a Dipidana dengan pidana penjara selama-lamanya lima tahun barangsiapa dengan sengaja di muka umum mengeluarkan perasaan atau melakukan perbuatan: a) yang pada pokoknya bersifat permusuhan, penyalahgunaan atau penodaan terhadap suatu agama yang dianut di Indonesia; b) dengan maksud agar supaya orang tidak menganut agama apapun juga, yang bersendikan ke-Tuhanan Yang Maha Esa. Lih. Muhammad Isnur (ed.), Agama, Negara dan Hak Asasi Manusia: Proses Pengujian UU 1/PNPS/1965 tentang Pencegahan, Penyalahgunaan, dan/atau Penodaan Agama di Mahkamah Konstitusi (Jakarta: Lembaga Bantuan Hukum Jakarta, 2012), 34-47. 
saya maksudkan adalah Undang-undang (UU) No.1/PNPS/1965 tentang Pencegahan, Penyalahgunaan dan/atau Penodaan Agama. Pertanyaan yang layak diajukan adalah apakah undang-undang ini membatasi KBB dalam kategori forum internum? Apakah undang-undang ini diputuskan melalui proses legislasi di parlemen, bukan hanya diputuskan oleh badan eksekutif secara sepihak?

Berdasarkan prinsip-prinsip implementasi KBB dan kemungkinan pembatasannya yang telah dibahas sebelumnya, bisa dikatakan bahwa UU No.1/PNPS/1965 tersebut merupakan pembatasan terhadap KBB yang tidak bisa dibenarkan. Artinya, secara prinsip, UU No.1/PNPS/1965 tidak sesuai dengan semangat penghormatan dan jaminan perlindungan atas KBB seperti dikemukakan dalam instrumen-instrumen HAM dan ratifikasinya dalam sistem hukum di Indonesia. Kesimpulan ini terutama didasarkan pada alasan bahwa UU No.1/PNPS/1965 telah melanggar syarat-syarat kemungkinan bagi pembatasan hak atas KBB sebagaimana termaktub dalam Kovenan Internasional Hak-hak Sipil dan Politik Pasal 18, yakni: (1) KBB pada kategori forum internum tidak bisa dibatasi atau dikurangi; dan (2) pembatasan terhadap KBB pada ketegori forum eksternum harus dibuat melalui proses legislasi di parlemen dan diperlukan untuk melindungi keselamatan, ketertiban, kesehatan dan moral masyarakat serta melindungi hak-hak dan kebebasan dasar orang lain. Sementara itu, UU No.1/PNPS/1965 dibuat secara sepihak oleh pemerintah tanpa melalui proses politik di Dewan Perwakilan Rakyat (DPR). Selain itu, substansi UU No.1/PNPS/1965 lebih banyak ditujukan untuk mendiskriminasi hak warga negara atas KBB daripada untuk melindungi hak-hak atas kebebasan dasar yang lebih besar lagi. 